\title{
PENGARUH KONSENTRASI KULIT KAYU MANIS (Cinnamomum verum) TERHADAP MUTU ORGANOLEPTIK IKAN LAYANG (Decapterus sp.) SELAMA PENYIMPANAN
}

\author{
Zulkifli Lahinta*1; Rahim Husain ${ }^{1}$; Asri Silvana Naiu1 \\ 1Jurusan Teknologi Hasil Perikanan, Fakultas Perikanan dan IImu Kelautan, Universitas Negeri Gorontalo, \\ JI.Jenderal Sudirman No.06, Kota Gorontalo 96128, Gorontalo, Indonesia \\ "Korespondensi: zulkiflilahinta@yahoo.com \\ (Diterima 03-03-2020; Direvisi 01-05-2020; Dipublikasi 07-05-2020)
}

\begin{abstract}
ABSTRAK
Mutu ikan yang digunakan sebagai bahan baku dalam pengolahan sangat berpengaruh terhadap kelancaran proses pengolahan, serta menentukan kualitas mutu produk yang dihasilkan. Penelitian ini bertujuan untuk mengetahui mutu organoleptik ikan layang (Decapterus sp.) yang dilumuri dengan kayu manis (Cinnamomum Verum) selama penyimpanan. Faktor perlakuan yaitu ikan layang yang diawetkan pada berbagai konsentrasi kayu manis $0 \%, 5 \%, 10 \%$ dan $15 \%$ yang diaplikasikan pada ikan segar selama 12 jam. Data organoleptik dianalisis dengan Kruskall-wallis. Data yang berpengaruh nyata diuji dengan uji lanjut Duncan. Hasil penelitian menunjukkan bahwa kayu manis memberikan pengaruh nyata terhadap uji mutu hedonik berupa kenampakan mata, insang, tekstur, bau, daging dan lendir. Perlakuan terbaik konsentrasi kayu manis yaitu perlakuan $10 \%$ dengan kriteria bola mata rata, kornea agak keruh, pupil agak keabu-abuan, agak mengkilap spesifik jenis ikan; insang merah muda atau coklat muda dengan sedikit lendir agak keruh; sayatan daging sedikit kurang cemerlang, jaringan daging kuat; tekstur agak lunak, agak elastis.
\end{abstract}

Kata kunci : Ikan Layang; Kayu Manis; Organoleptik; Penyimpanan.

\section{ABSTRACT}

The quality of fish used as raw material in processing is very influential on the smoothness of the processing process, as well as determining the quality of the products produced. This study aims to determine the organoleptic quality of flying fish (Decapterus sp.) Smeared with cinnamon (Cinnamomum Verum) during storage. The treatment factor was that the floating fish were preserved at various concentrations of cinnamon $0 \%, 5 \%, 10 \%$ and $15 \%$ which were applied to fresh fish for 12 hours. Organoleptic data were analyzed by Kruskall-wallis. Significantly influential data was tested by Duncan's further test. The results showed that cinnamon had a real effect on the hedonic quality test in the form of eye appearance, gills, texture, odor, meat and mucus. The best treatment of cinnamon concentration is $10 \%$ treatment with criteria of flat eyeballs, slightly cloudy corneas, slightly grayish pupils, rather shiny specific species of fish; pink or light brown gills with a slightly cloudy mucus; sliced flesh slightly less brilliant, strong flesh tissue; texture rather soft, somewhat elastic.

Keywords: Cinnamon verum; Decapturs sp.; Organoleptic; Storage. 


\section{PENDAHULUAN}

Ikan layang di Indonesia khususnya Gorontalo sangat melimpah. Potensi ikan layang pada tahun 2018 mencapai 5.226 ton (DKP Gorontalo, 2018). Ikan layang termasuk salah satu komiditi pangan laut yang mudah mengalami kemunduran mutu. Hal ini disebabkan oleh kandungan protein yang tinggi yaitu sekitar $18-30 \%$, kandungan air sekitar 60 $84 \%$ dan kondisi lingkungan yang sangat sesuai untuk pertumbuhan mikroba pembusuk. Kondisi lingkungan tersebut yaitu suhu, $\mathrm{pH}$, oksigen, waktu simpan dan kondisi kebersihan sarana prasarana (Astawan, 2004).

Menurut Irianto dan Giyatmi (2004) mutu ikan yang digunakan sebagai bahan baku di dalam pengolahan sangat berpengaruh terhadap kelancaran proses pengolahan dan berpengaruh juga terhadap mutu produk yang dihasilkan. Semakin tinggi mutu ikan yang digunakan dapat diperkirakan bahwa proses pengolahan akan berjalan semakin lancar dan peluang untuk menghasilkan produk bermutu tinggi akan semakin besar. Oleh karena itu, syarat utama yang pertama kali harus dipenuhi dalam proses pengolahan ikan adalah tersedianya bahan baku ikan bermutu tinggi. Selain itu, sampai saat ini belum ada teknologi yang dapat menjadikan ikan bermutu rendah diubah atau ditingkatkan mutunya menjadi ikan bermutu tinggi. Dengan menggunakan teknologi yang ada, hal yang dapat dilakukan terhadap mutu ikan adalah mempertahankan mutu ikan jangan sampai menurun atau berkurang tingkat kesegarannya. Hal ini sangat penting untuk diperhatikan, mengingat ikan termasuk salah satu bahan yang mudah sekali rusak atau busuk. Iklim tropis Indonesia dengan suhu dan kelembaban yang tinggi sangat mendukung terhadap proses pembusukan ikan sehingga memungkinkan kerusakan ikan berlangsung dengan cepat bila tidak ada upaya untuk menghambatnya.

Proses pengawetan ikan merupakan salah satu bagian penting dari mata rantai industri perikanan, dimana pengawetan bertujuan mempertahankan kesegaran ikan selama mungkin dengan cara menghambat penyebab kemunduran mutu. Perubahan mutu kesegaran dapat berlangsung secara enzimatis, kimia dan bakteriologi dengan diikuti penurunan organoleptik yang dipengaruhi oleh keadaan temperatur, dimana semakin tinggi suhu, semakin cepat pula penurunan mutu kesegaran (Afrianto dan Liviawaty, 1989 dalam Pianusa, 2015). Untuk mempertahankan mutu kesegaran dapat dilakukan penanganan dengan menggunakan es dan bahan pengawet alami untuk mempertahankan kesegaran ikan. Bahan alami yang berpotensi digunakan untuk pengawetan ikan salah satunya adalah kayu manis (Cinnamomum verum).

Kayu manis mengandung antara lain minyak atsiri, safrole, sinamaldehida, tannin, dammar, kalsium oksalat, flavonoid, triterpenoid, dan saponin (Utami, 2013). Minyak 
atsiri banyak terdapat dibagian kulit kayu manis. Kandungan terbanyak dalam minyak atsiri kulit kayu manis adalah sinamaldehid $60-70 \%, p$ cimene $0,6-1,2 \%$, a-pinene $0,2-0,6 \%$, eugenol $0,8 \%$, sinamil asetat $5 \%$, kariofilen $1,4-3,3 \%$, benzil benzoate $0,7-1,0 \%$. Komponen minyak atsiri tersebut memiliki aktivitas sebagai antibakteri terhadap $E$. coli dan $S$. aureus (Balchin, 2006). Nisa (2014) melaporkan bahwa ekstrak kulit kayu manis memiliki aktivitas antibakteri dalam menghambat bakteri $E$. coli dan S. aureus. Namun, komponen-komponen kimia dalam minyak atsiri mudah menguap, teroksidasi dan juga mudah terkendali. Sehingga diduga sifat antimikroba dapat menurun selama penyimpanan, oleh sebab itu, dalam penelitian ini perlu diuji. Penelitian yang akan dilakukan untuk mengetahui mutu organoleptik ikan layang (Decapterus sp.) yang dilumuri dengan kayu manis (Cinnamomum Verum) selama penyimpanan.

Penggunaan kayu manis yang terlalu banyak dikhawatirkan dapat mempengaruhi rasa. Namun penggunaan dalam jumlah yang sedikit juga tidak efektif dalam menghambat pertumbuhan mikroba.

Berdasarkan uraian tersebut penulis perlu melakukan penelitian dengan judul "Pengaruh Perbandingan Konsentrasi Kulit Kayu Manis (Cinnamomum verum) Terhadap Kesegaran Ikan Layang (Decapterus sp.) Selama Penyimpanan".

\section{METODE PENELITIAN}

Waktu dan Tempat penelitian

Pelaksanaan penelitian ini dilaksanakan pada bulan Januari sampai dengan Agustus tahun 2018. Pengujian organoleptik bertempat dilaboratorium Jurusan Teknologi Hasil Perikanan Fakultas Perikanan dan IImu Kelautan Universitas Negeri Gorontalo.

\section{Alat dan bahan}

Alat yang digunakan pada penelitian antara lain coolbox sebagai wadah penyimpanan, score sheet organoleptik. Bahan yang digunakan adalah kayu masis, sampel ikan layang segar segar untuk pengujian sampel.

\section{Prosedur Penelitian}

Prosedur penelitian mengenai mutu organoleptik ikan layang segar berdasarkan penggunaan kayu manis diawali dengan penentuan konsentrasi kayu manis. Penelitian penggunaan kayu manis sebagai pengawet ini, mengacu pada Nurkamiden (2018), namun sedikit modifikasi oleh peneliti. Adapun konsentrasi kayu manis yang digunakan yaitu $0 \%, 5 \%, 10 \%$, dan $15 \%$ pada lama penyimpanan 12 jam. Sampel ikan layang dibeli dari tempat pelelangan ikan (TPI) Tenda Kota Gorontalo. Kayu manis diambil dari kota Gorontalo. Pembuatan konsentrasi kayu manis yakni dengan melarutkan sejumlah (gr) kayu manis yang telah dihaluskan dalam aquades $(\mathrm{ml})$. 
Pengambilan sampel ikan layang segar diperoleh dari TPI Tenda Kota Gorontalo sebanyak $4 \mathrm{Kg}$. Selanjutnya, ikan layang dibawa ke tempat pengujian BPPMHP dalam cool box sterofoam yang berisi es dengan perbandingan 1:1. Di BPPMHP, ikan layang segar dicuci dan ditimbang kembali menjadi 1 $\mathrm{kg}$ untuk dipakai pada masing-masing perlakuan konsentrasi $(0 \%, 5 \%, 10 \%, 15 \%)$. Selanjutnya, ikan layang segar direndam dengan kayu manis dalam cool box selama penyimpanan 12 jam. Setelah 12 jam dilakukan pengujian organoleptik (mutu hedonik).

\section{HASIL DAN PEMBAHASAN}

\section{Kenampakan Mata}

Histogram hasil pengujian mutu ikan nila dapat dilihat pada Gambar 1.

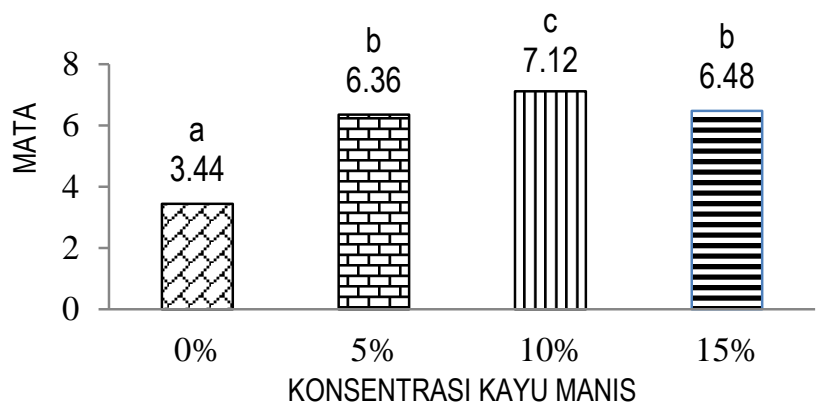

Gambar 1. Histogram hasil uji mutu hedonik kenampakan mata ikan layang dengan konsentrasi kayu manis yang berbeda.

Histogram Gambar 1 menunjukkan bahwa data hasil penelitian uji mutu hedonik menunjukkan bahwa kenampakan ikan layang berada pada interval $3,44-7,12$. Nilai terendah terdapat pada perlakuan konsentrasi kayu manis $0 \%$ dan nilai tertinggi terdapat pada

http://ejurnal.ung.ac.id/index.php/jpj/issue/arch perlakuan $10 \%$. Mengacu pada standar mutu ikan segar yang ditetapkan oleh BSN (27292013) bahwa mata ikan layang hasil pada konsentrasi $10 \%$ memenuhi syarat nilai organoleptik yakni 7 , sedangkan pada konsentrasi $0 \%, 5 \%$ dan $15 \%$ belum memenuhi persyaratan SNI.

Berdasarkan uji Kruskal Wallis perlakuan konsentrasi kayu manis yang berbeda berpengaruh nyata terhadap kenampakan mata ikan layang yang dihasilkan. Hasil uji Duncan menunjukkan bahwa konsentrasi kayu manis $10 \%$ berbeda nyata dengan $0 \%, 5 \%$ dan $15 \%$, sedangkan $5 \%$ dan $15 \%$ tidak berbeda nyata. Perlakuan 10\% memenuhi BSN (2729-2013) karena ikan layang memiliki nilai mutu hedonik secara statistik yaitu 7,12 dibulatkan 7 dengan kriteria bola mata rata, kornea agak keruh, pupil agak keabu-abuan, agak mengkilap spesifik jenis ikan. Namun berbeda dengan perlakuan $0 \%$ memiliki nilai mutu hedonik secara statistik 3,44 dibulatkan 3 yaitu dengan kriteria bola mata cekung, kornea keruh, pupil keabu-abuan, tidak mengkilap. Pada konsentrasi 5\% dan 15\% memiliki nilai mutu hedonik secara statitistik sama dibulatkan 6 dengan kriteria bola mata agak cekung, kornea agak keruh, pupil agak keabu-abuan, agak mengkilap spesifik jenis ikan.

Hasil penelitian menunjukkan bahwa pada konsentrasi kayu manis 10\% nilai organoleptik kenampakan mata lebih ditinggi dibandingkan dengan $0 \%, 5 \%$ dan $15 \%$. Pada konsentrasi 
kayu manis $0 \%, 5 \%$ dan $15 \%$ nilai organoleptik kenampakan mata ikan layang menurun. Penurunan nilai organoleptik berkaitan erat dengan aktivitas bakteri pada ikan layang yang semakin naik karena penggunan antimikroba yaitu larutan kayu manis tidak efektif lagi dalam mempertahankan mutu ikan layang. Hal ini sesuai dengan penelitian yang dilakukan oleh Nurkamiden (2018) menunjukkan bahwa nilai orgaoleptik ikan nila dengan konsentrasi kayu manis yang lebih banyak $(5 \%, 7 \%, 10 \%)$ tidak memenuhi SNI ikan segar.

Penurunan nilai organoleptik disebabkan karena ketidakmampuan antibiotik melakukan fungsinya terhadap bakteri atau disebut dengan resistensi antibiotik. Resistensi dapat terjadi dengan cara melakukan inaktivasi antibiotik, dimana bakteri dapat memproduksi enzim yang akan memecah struktur kimia dari antibiotik sehingga antibiotik tidak dapat berfungsi. Salah satunya adalah enzim beta laktamase yang diproduksi oleh bakteri golongan Enterobacteriaceae. Beberapa bakteri dilaporkan dapat memproduksi enzim yang dapat menginaktivasi satu antibiotik atau beberapa antibiotik (Guilfole, 2007)

\section{Insang}

Histogram hasil pengujian mutu ikan layang dapat dilihat pada Gambar 2.

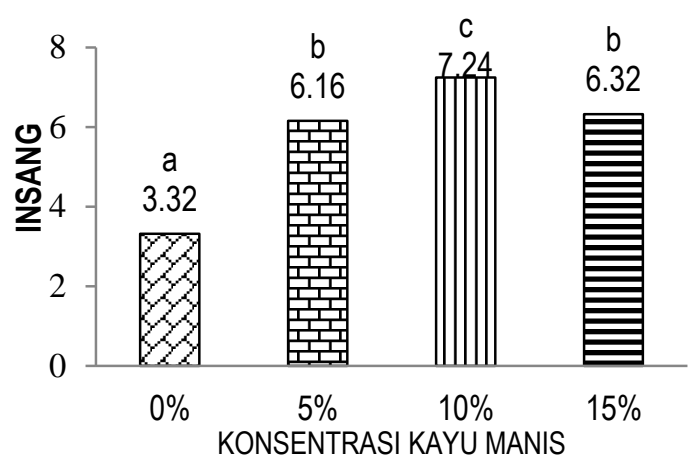

Gambar 2. Histogram hasil uji mutu hedonik kenampakan insang ikan layang dengan konsentrasi kayu manis yang berbeda.

Histogram Gambar 2 menunjukkan bahwa data hasil penelitian uji mutu hedonik menunjukkan bahwa kenampakan insang ikan layang berada pada interval $3,32-7,24$. Nilai terendah terdapat pada konsentrasi $0 \%$ dan nilai tertinggi terdapat pada konsentrasi $10 \%$. Mengacu pada standar mutu ikan segar yang ditetapkan oleh BSN (2729-2013) bahwa insang ikan layang hasil perlakuan dengan konsentrasi $10 \%$ memenuhi syarat dengan nilai organoleptik yakni 7, sedangkan pada konsentrasi $0 \%, 5 \%$ dan $15 \%$ belum memenuhi persyaratan SNI.

Berdasarkan uji Kruskal Wallis perlakuan konsentrasi kayu manis yang berbeda berpengaruh nyata terhadap kenampakan insang ikan layang yang dihasilkan. Hasil uji Duncan menunjukkan bahwa konsentrasi kayu manis $10 \%$ berbeda nyata dengan $0 \%, 5 \%$ dan $15 \%$, sedangkan $5 \%$ dan $15 \%$ tidak berbeda nyata.

Perlakuan konsentrasi 10\%, ikan layang memiliki nilai mutu hedonik secara statitistik yaitu 7,24 dibulatkan 7 dengan kriteria warna 
insang merah muda atau coklat muda dengan sedikit lendir agak keruh. Namun berbeda pada konsentrasi $0 \%$ memiliki nilai mutu hedonik secara statistik 3,32 dibulatkan 3 yaitu dengan kriteria warna insang abu-abu atau coklat keabuabuan dengan lendir putih susu bergumpal. Pada konsentrasi 5\% dan 15\% memiliki nilai mutu hedonik secara statitistik sama yang dibulatkan 6 dengan kriteria warna insang merah muda atau coklat muda dengan lendir agak keruh.

Hasil penelitian menunjukkan bahwa pada konsentrasi kayu manis 10\% nilai organoleptik insang lebih ditinggi dibandingkan dengan $0 \%$, $5 \%$ dan $15 \%$. Pada konsentrasi kayu manis $0 \%$, $5 \%$ dan $15 \%$ nilai organoleptik kenampakan mata ikan layang menurun. Penurunan nilai organoleptik berkaitan erat dengan aktivitas bakteri pada ikan layang. Tingginya nilai organoleptik ikan layang yang dilumuri kayu manis $10 \%$ dapat dihambat oleh penggunaan anti bakteri dari kayu manis itu sendiri yaitu minyak atsiri.

Semakin banyaknya konsentrasi kayu manis yang digunakan yaitu $15 \%$, antibakteri pada kayu manis tidak lagi berfungsi sebagaimana mestinya, hal ini dilihat dari nilai organoleptik yang semakin menurun. Penurunan nilai organoleptik tersebut disebabkan karena ada beberapa jenis bakteri seperti Escherichia coli yang resisten terhadap antibiotik atau antibakteri. Menurut Widjajanti (1999) hal ini disebabkan bakteri telah http://ejurnal.ung.ac.id/index.php/jpj/issue/arch mengadakan mutasi yang dapat terjadi karena pengobatan yang dilakukan tidak dengan semestinya.

\section{Lendir}

Histogram hasil pengujian mutu ikan dapat dilihat pada Gambar 3.

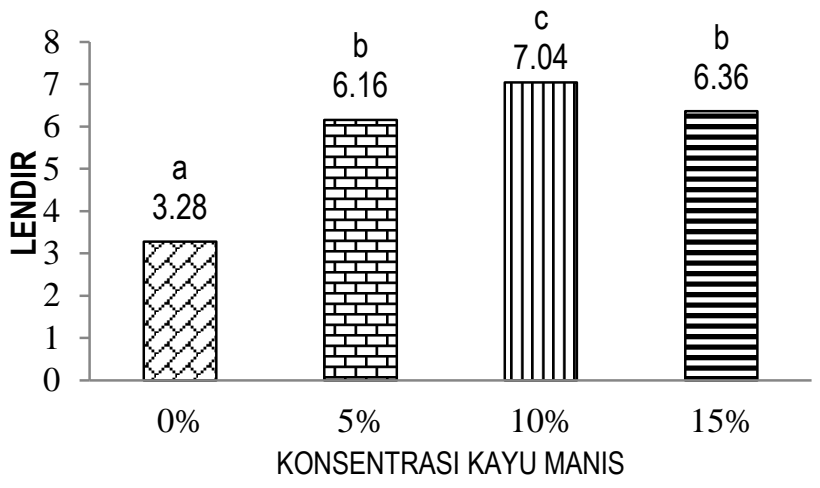

Gambar 3. Histogram hasil uji mutu hedonik kenampakan lendir ikan nila dengan lama penyimpanan yang berbeda.

Histogram Gambar 3 menunjukkan bahwa data hasil penelitian uji mutu hedonik menunjukkan bahwa kenampakan lendir ikan layang berada pada interval $3,26-7,24$. Nilai terendah terdapat pada konsentrasii $0 \%$ dan nilai tertinggi terdapat pada konsentrasi $10 \%$. Mengacu pada standar mutu ikan segar yang ditetapkan oleh BSN (2729-2013) bahwa insang ikan layang hasil perlakuan dengan konsentrasi $10 \%$ memenuhi syarat dengan nilai organoleptik yakni 7, sedangkan pada konsentrasi $0 \%, 5 \%$ dan $15 \%$ belum memenuhi persyaratan SNI.

Berdasarkan uji Kruskal Wallis perlakuan konsentrasi kayu manis yang berbeda berpengaruh nyata terhadap kenampakan lendir ikan layang yang dihasilkan. Hasil uji Duncan menunjukkan bahwa konsentrasi kayu 
manis $10 \%$ berbeda nyata dengan $0 \%, 5 \%$ dan $15 \%$, sedangkan $5 \%$ dan $15 \%$ tidak berbeda nyata.

Konsentrasi kayu manis $10 \%$ pada ikan layang memiliki nilai mutu hedonik secara statistik yaitu 7,04 yang dibulatkan 7 dengan kriteria lapisan lendir mulai agak keruh. Namun berbeda dengan perlakuan $0 \%$ memiliki nilai mutu hedonik secara statistik 3,28 dibulatkan 3 dengan kriteria lendir tebal sedikit menggumpal berubah warna. Serta pada konsentrasi $5 \%$ dan $15 \%$ memiliki nilai mutu hedonik secara statitistik sama yang dibulatkan 6 dengan kriteria lapisan lendir mulai keruh.

Hasil penelitian menunjukkan bahwa pada konsentrasi kayu manis 10\% nilai organoleptik kenampakan lendir lebih ditinggi dibandingkan dengan $0 \%, 5 \%$ dan 15\%. Pada konsentrasi kayu manis $0 \%, 5 \%$ dan $15 \%$ nilai organoleptik kenampakan mata ikan layang menurun. Semakin banyak konsentrasi kayu manis yang digunakna nilai mutu hedonik lendir ikan layang semakin menurun, hal ini berkaitan dengan adanya aktivitas bakteri yang memanfaatkan lendir ikan. Berdasarkan DKP (2008), mikroba banyak ditemukan di permukaan luar tubuh ikan (kulit dan insang) dan usus ikan segar. Menurut Djojosentono (1982) salah satu perubahan setelah ikan mati yaitu lendir terlepas dari kelenjar-kelenjar yang ada di dalam kulit, membentuk lapisan bening yang tebal disekeliling tubuh ikan. Lendir itu terdiri dari gluco protein dan menjadi substrat yang baik http://ejurnal.ung.ac.id/index.php/jfpj/issue/arch bagi pertumbuhan bakteri. Sehingga perlu adanya kayu manis sebagai antibakteri, namun semakin banyak konsentrasi yang digunakan antibakteri pada kayu manis tidak lagi berfungsi sebagaimana mestinya.

\section{Daging}

Histogram hasil pengujian mutu ikan layang dapat dilihat pada Gambar 4.

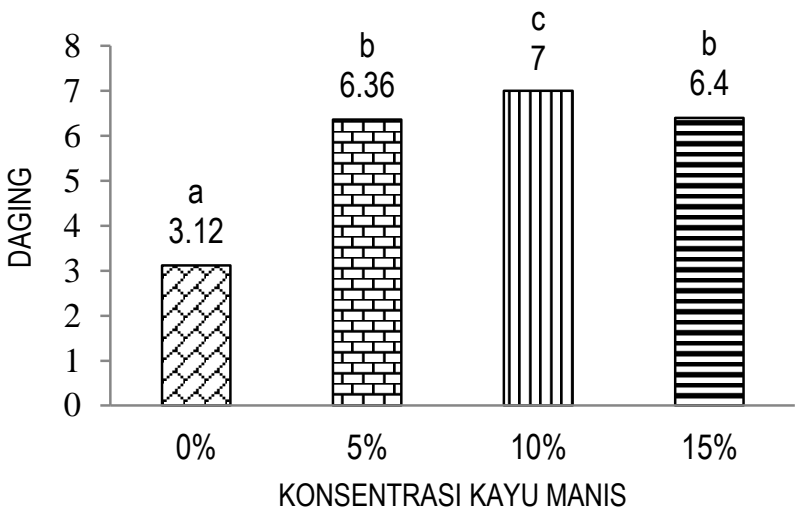

Gambar 4. Histogram hasil uji mutu hedonik daging ikan layang dengan konsentrasi kayu manis yang berbeda.

Histogram Gambar 4 menunjukkan bahwa data hasil penelitian uji mutu hedonik menunjukkan bahwa daging ikan nila berada pada interval 3,12 -7 . Nilai terendah terdapat pada konsentrasii $0 \%$ dan nilai tertinggi terdapat pada konsentrasi 10\%. Mengacu pada standar mutu ikan segar yang ditetapkan oleh BSN (2729-2013) bahwa daging ikan layang hasil perlakuan dengan konsentrasi 10\% memenuhi syarat dengan nilai organoleptik yakni 7 , sedangkan pada konsentrasi $0 \%, 5 \%$ dan $15 \%$ belum memenuhi persyaratan SNI.

Berdasarkan uji Kruskal Wallis perlakuan konsentrasi kayu manis yang berbeda berpengaruh nyata terhadap daging ikan layang yang dihasilkan. Hasil uji Duncan 
menunjukkan bahwa konsentrasi kayu manis $10 \%$ berbeda nyata dengan $0 \%, 5 \%$ dan $15 \%$, sedangkan $5 \%$ dan $15 \%$ tidak berbeda nyata.

Konsentrasi kayu manis $10 \%$ pada ikan layang memiliki nilai mutu hedonik secara statitistik yaitu 7 dengan sayatan daging sedikit kurang cemerlang, jaringan daging kuat. Namun berbeda dengan perlakuan $0 \%$ memiliki nilai mutu hedonik secara statistik 3,12 dibulatkan 3 dengan kriteria sayatan daging kusam, jaringan daging kurang kuat. Konsentrasi kayu manis 5\% dan 15\% memiliki nilai mutu yang sama yaitu dibulatkan 6 dengan kriteria sayatan daging kurang cemerlang, jaringan daging sedikit kurang kuat.

Hasil penelitian menunjukkan bahwa pada konsentrasi kayu manis 10\% nilai organoleptik daging ikan layang lebih ditinggi dibandingkan dengan $0 \%, 5 \%$ dan 15\%. Pada konsentrasi kayu manis $0 \%, 5 \%$ dan $15 \%$ nilai organoleptik kenampakan mata ikan layang menurun. Hal ini berkaitan dengan adanya aktivitas bakteri. Sehingga perlu adanya kayu manis sebagai antibakteri, namun penggunaan kayu manis yang banyak (15\%) antibakteri pada kayu manis tidak lagi berfungsi sebagaimana mestinya..

\section{Bau}

Histogram hasil pengujian mutu ikan layang dapat dilihat pada Gambar 5.

Histogram Gambar 5 menunjukkan bahwa data hasil penelitian uji mutu hedonik menunjukkan bahwa bau ikan layang berada pada interval $3,48-7,24$. Nilai terendah terdapat pada konsentrasii $0 \%$ dan nilai tertinggi terdapat pada konsentrasi 10\%. Mengacu pada standar mutu ikan segar yang ditetapkan oleh BSN (2729-2013) bahwa bau ikan layang hasil perlakuan dengan konsentrasi $10 \%$ memenuhi syarat dengan nilai organoleptik yakni 7, sedangkan pada konsentrasi $0 \%, 5 \%$ dan $15 \%$ belum memenuhi persyaratan SNI.

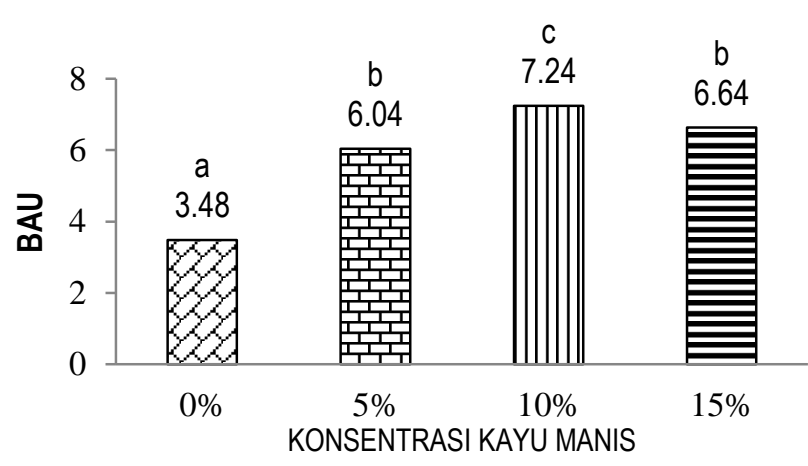

Gambar 5. Histogram hasil uji mutu hedonik bau ikan layang dengan konsentrasi kayu manis yang berbeda.

Berdasarkan uji Kruskal Wallis perlakuan konsentrasi kayu manis yang berbeda berpengaruh nyata terhadap bau ikan layang yang dihasilkan. Hasil uji Duncan menunjukkan bahwa konsentrasi kayu manis 10\% berbeda nyata dengan $0 \%, 5 \%$ dan $15 \%$, sedangkan $5 \%$ dan $15 \%$ tidak berbeda nyata.

Perlakuan konsentrasi kayu manis 10\% pada ikan layang memiliki nilai mutu hedonik secara statitistik yaitu 7,24 dibulatkan 7 dengan kriteria segar, spesifik jenis kurang. Namun berbeda dengan perlakuan konsentrasi $0 \%$ memiliki nilai mutu hedonik secara statistik 3,48 dibulatkan 3 dengan kriteria bau asam kuat. 
Konsentrasi $5 \%$ dan $15 \%$ memiliki nilai mutu hedonik yang sama dibulatkan 6 dengan kriteria netral.

Bau khas ikan segar untuk ikan layang mengalami penurunan mutu yang menyebabkan nilai organoleptik bau juga ikut menurun. Bau amis (amoniak) ini timbul dari ikan, merupakan hasil samping penguraian protein oleh aktivitas bakteri. Dari bau amoniak tersebut berangsur-angsur mengarah pada bau busuk. Kebusukan ikan disebabkan karena aktivitas mikroba penyebab kerusakan ikan. Pembusukan tersebut tersebut terjadi karena adanya proses pemecahan protein menjadi molekul-molekul sederhana seperti asam amino sehingga sel-sel pada tubuh ikan menjadi rusak dan membusuk (Ariyani et al. 2007)

\section{Tekstur}

Histogram hasil pengujian mutu ikan nila dapat dilihat pada Gambar 6.

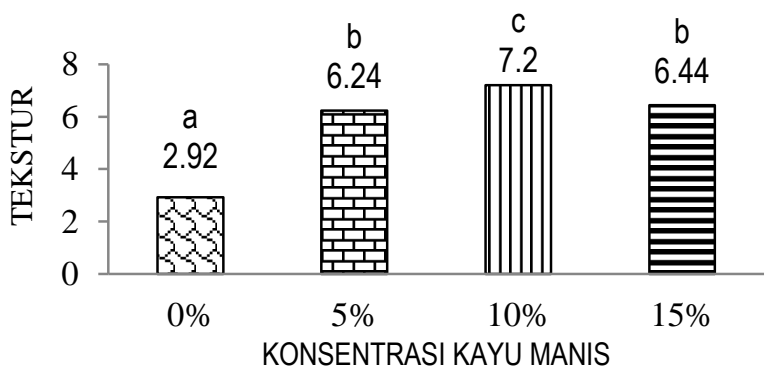

Gambar 6. Histogram hasil uji mutu hedonik tekstur ikan layang dengan konsentrasi kayu manis yang berbeda.

Histogram Gambar 6 menunjukkan bahwa data hasil penelitian uji mutu hedonik menunjukkan bahwa tekstur ikan nila berada pada interval 2,92 -7,2. Nilai terendah terdapat http://ejurnal.ung.ac.id/index.php/jpj/issue/arch pada konsentrasii $0 \%$ dan nilai tertinggi terdapat pada konsentrasi 10\%. Mengacu pada standar mutu ikan segar yang ditetapkan oleh BSN (2729-2013) bahwa tekstur ikan layang hasil perlakuan dengan konsentrasi 10\% memenuhi syarat dengan nilai organoleptik yakni 7 , sedangkan pada konsentrasi $0 \%, 5 \%$ dan $15 \%$ belum memenuhi persyaratan SNI.

Berdasarkan uji Kruskal Wallis perlakuan konsentrasi kayu manis yang berbeda berpengaruh nyata terhadap tekstur ikan layang yang dihasilkan. Hasil uji Duncan menunjukkan bahwa konsentrasi kayu manis $10 \%$ berbeda nyata dengan $0 \%, 5 \%$ dan $15 \%$, sedangkan $5 \%$ dan $15 \%$ tidak berbeda nyata.

Perlakuan konsentrasi kayu manis 10\% pada ikan layang memiliki nilai mutu hedonik secara statitistik yaitu 7,2 dibulatkan 7 dengan kriteria agak lunak, agak elastis. Namun berbeda dengan perlakuan $0 \%$ memiliki nilai mutu hedonik secara statistik 2,92 dibulatkan 3 yaitu lunak bekas jari terlihat dan sangat lambat hilang. Konsentrasi 5\% dan 15\% memiliki nilai mutu hedonik yang sama yaitu dibulatkan 6 dengan kriteria agak lunak, sedikit kurang elastis.

Hasil penelitian menunjukkan bahwa pada konsentrasi kayu manis 10\% nilai organoleptik kenampakan mata lebih ditinggi dibandingkan dengan $0 \%, 5 \%$ dan $15 \%$. Pada konsentrasi kayu manis $0 \%, 5 \%$ dan $15 \%$ nilai organoleptik kenampakan mata ikan layang menurun. Penurunan nilai organoleptik mutu tekstur ikan 
layang disebabkan oleh aktivitas sejumlah bakteri dan enzim perusak yang terdapat pada ikan. Penurunan mutu tersebut dapat dicegah dengan penggunaan antibakteri untuk menghambat kinerja bakteri dan enzim penyebab kerusakan. Penggunaan kayu manis $10 \%$ sebagai bahan pengawet mampu mempertahankan mutu organoleptik tekstur ikan layang sampai dengan lama penyimpanan 12 jam. Bahan kayu manis yang mengandung antibakteri berupa senyawa minyak atsiri memberikan peran yang begitu penting dalam mempertahankan tekstur ikan layang.

\section{Rasa Sesudah Digoreng}

Histogram hasil pengujian mutu ikan nila dapat dilihat pada Gambar 7.

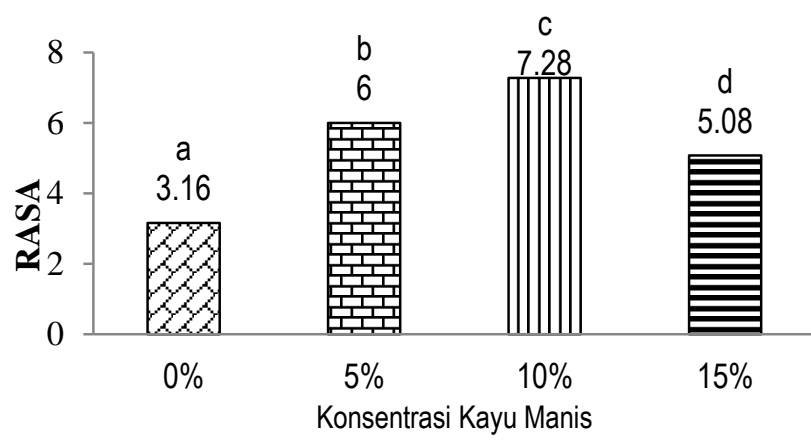

Gambar 7. Histogram hasil uji mutu hedonik rasa ikan layang dengan konsentrasi kayu manis yang berbeda.

Histogram Gambar 7 menunjukkan bahwa data hasil penelitian uji mutu hedonik menunjukkan bahwa tekstur ikan nila berada pada interval 3,16 - 7,28. Nilai terendah terdapat pada konsentrasii $0 \%$ dan nilai tertinggi terdapat pada konsentrasi $10 \%$. Mengacu pada standar mutu ikan segar yang ditetapkan oleh BSN (2729-2013) bahwa rasa ikan layang sesudah digoreng tidak disyaratkan dalam SNI ikan segar tersebut.

Berdasarkan uji Kruskal Wallis perlakuan konsentrasi kayu manis yang berbeda berpengaruh nyata terhadap rasa ikan layang yang dihasilkan. Hasil uji Duncan menunjukkan bahwa konsentrasi kayu manis $0 \%, 5 \%, 10 \%$ dan $15 \%$ semua berbeda nyata.

Perlakuan konsentrasi kayu manis 10\% pada ikan layang memiliki nilai mutu hedonik secara statitistik yaitu 7,28 dibulatkan 7 dengan kriteria rasa gurih ikan dan bumbu kayu manis. Namun berbeda dengan perlakuan $0 \%$ memiliki nilai mutu hedonik secara statistik 3,16 dibulatkan 3 yaitu tidak berasa bumbu kayu manis. Konsentrasi $5 \%$ memiliki nilai mutu hedonik yaitu 6 dengan kriteria sangat gurih bumbu kayu manis. Serta konsentrasi 15\% memiliki nilai mutu hedonik 5,08 dibulatkan 5 dengan kriteria gurih bumbu kayu manis.

\section{SIMPULAN}

Berdasarkan hasil penelitian menunjukkan bahwa penggunaan kayu manis (Cinnamomum verum) terhadap tingkat kesegaran ikan layang (Decapterus sp.), maka dapat disimpulkan bahwa penggunaan kayu manis dengan konsentrasi $0 \%, \quad 5 \%, \quad 10 \%$ dan $15 \%$ memberikan pengaruh nyata terhadap uji mutu hedonik berupa kenampakan mata, insang, tekstur, bau, daging dan lendir. Perlakuan terbaik konsentrasi kayu manis yaitu perlakuan $10 \%$ dengan kriteria bola mata rata, kornea 
agak keruh, pupil agak keabu-abuan, agak mengkilap spesifik jenis ikan; insang merah muda atau coklat muda dengan sedikit lendir agak keruh; sayatan daging sedikit kurang cemerlang, jaringan daging kuat; tekstur agak lunak, agak elastis.

\section{DAFTAR PUSTAKA}

Afrianto, E., Liviawaty, E. 2011. Pengawetan dan Pengolahan Ikan. Yogyakarta.

Astawan, M. 2004. Ikan yang Sedap dan Bergizi. Tiga Serangkai. Surakarta.

Ariyani, F., Murtini, J.T., Indriati, N., Dwiyitno, Yenni, Y. 2007. Penggunaan Glyroxyl untuk Menghambat Penurunan Mutu Ikan Mas (C. Carpio) Segar. Jurnal Perikanan. 9(1): 125-133.

Badan Karantika Ikan, Pengendalian Mutu dan Keamanan Hasil Perikanan. 2017. Keputusan Kepala BKIPMHP tentang Petunjuk Teknis Surveilan Kesegarab Ikan, Residu, Bahan Berbahaya, Racun Hayati Laut (Marine Biotoxin), dan Lingkungan Perairan. Kementerian Kelautan dan Perikanan. Jakarta.

Badan Standarisasi Nasional Indonesia. 2013. Ikan Segar SNI 2729-2013. Dewan Standarisasi Nasional Indonesia. Jakarta.

Badan Standarisasi Nasional [BSN]. 2006. SNI 01-2332-3-2006, Cara Uji Mikrobiologi Bagian 3: Penentuan angka lempeng total (ALT) pada Produk Perikanan. Badan Standarisasi Nasional. Jakarta.

Badan Pusat Statistik (BPS), diakses dari http://www.bps.go.id/, diaksespada tanggal 5 Desember 2017.

http://ejurnal.ung.ac.id/index.php/jpj/issue/arch
Balchin, M.L. 2006. Aromatheraphy science. 1st Ed. London: Pharmaceutical Press.

Dinas Perikanan Kelautan Provinsi Gorontalo. 2016. Data Perikanan Budidaya 2016. Gorontalo.

Djojosentono, S., dan Karyono, S. 1982. Teknik Penanganan dan Pengolahan Ikan. Departemen Pendidikan dan Kebudayaan. Direktorat Pendidikan Menengah Kejuruan.

Food and Agriculture Organization [FAO]. 1995. Quality and Quality Changes in Fresh Fish. Di dalam: Huss HH, editor. Roma: FAO Fisheries Technical Paper 331: 065.

Nisa, L.C. 2014. Aktivitas Antibakteri Kulit Kayu Manis (Cinnamomum burmanni) dengan Cara Ekstraksi yang Berbeda Terhadap Escherichia coli dan Staphylococcus aureus. Skripsi. Universitas Muhammadiyah Surakarta.

Nurkamiden, R. 2018. Pengaruh Lama Penyimpanan Terhadap Kesegaran Ikan Nila (Oreochromis niloticus) yang Dilumuri Dengan Kayu Manis (Cinnamomum verum). Skripsi. Fakultas Perikanan dan Ilmu Kelautan. Universitas Negeri Gorontalo. Gorontalo.

Utami, P., Puspaningtyas, D.S. 2013. The Miracle of Herbs. Agro Media Pustaka. Jakarta.

Widjajanti, V.N. 1999. Obat - Obatan. Kanisius. Yogyakarta 